\title{
Severity Level and Quality of Life of Post- Acute Coronary Syndrome Patients
}

\author{
Donny Nurhamsyah*®, Yanny Trisyani®, Aan Nuraeni $\odot$, Nur Maziyya \\ Faculty of Nursing, Universitas Padjadjaran, Bandung, Indonesia
}

\section{G open access}

\section{Jurnal Keperawatan Padjadjaran (JKP)}

Volume 9(2), 118-123 (C) The Author(s) 2021 http://dx.doi.org/10.24198/jkp. v9i2.1661

\section{Article Info}

Received : Mei 20, 2021

Revised : July 5, 2021

Accepted : July 12, 2021

Published : August 31, 2021

\section{Corresponding author}

Donny Nurhamsyah

Department of Medical Surgical

Nursing, Faculty of Nursing,

Universitas Padjadjaran, Bandung,

Indonesia, Postal address: 45363 phone: 62 85230848493, e-mail:

donny.nurhamsyah@unpad.ac.id

\section{Citation}

Nurhamsyah, D., Trisyani, Y., Nuraeni, A., \& Maziyya, N. (2021) Severity Level and Quality of Life of Post-Acute Coronary Syndrome Patients. Jurnal Keperawatan Padjadjaran, 9(2), 118-123.https:// doi.org/10.24198/jkp.v9i2.1661

\section{Website}

http://jkp.fkep.unpad.ac.id/index. php/jkp

This is an Open Access article distributed under the terms of the Creative Commons Attribution-NonCommercial 4.0 International License.

E-ISSN: $2442-7276$

P-ISSN: 2338-5324

\begin{abstract}
Background: Severity level is one of the variables used to determine the treatments of acute coronary syndrome patients. There are many ways to see the success of treatment such as measuring the patient's quality of life. Purpose: This study aims to determine the correlation between severity level and quality of life among patients with post-acute coronary syndrome at Hasan Sadikin Central Hospital Bandung.

Methods: This research was a quantitative study with a descriptive-analytic approach. Sampling of 100 patients with post-acute coronary syndrome patients was collected during a period of one month using consecutive sampling technique. The severity was assessed based on the stenosis number and the quality of life data were collected using the MacNew QLMI. Somers'd Gamma was used to analyze the data.

Results: Data showed that most of the patients had angina without stenosis $(36 \%)$ and coronary 1 stenosis (29\%). The results of the quality of life measurement show that $58 \%$ patients have a good quality of life, $64 \%$ are good in the emotional domain, $52 \%$ are good in the physical domain, and $60 \%$ are good in the social domain. Bivariate analysis (Cl 95\%) showed that there was a significant correlation between severity level and quality of life ( $p$-value 0.033 ), as well as with the physical domain ( $p$-value 0,008 ).

Conclusion: There is a correlation between severity level and quality of life of post-acute coronary syndrome patients in Hasan Sadikin Central Hospital Bandung. Based on the quality of life domain, the severity level was significantly related to the physical-domain. Regular screening is necessary to improve the quality of life of post-acute coronary syndrome patients.
\end{abstract}

Keywords: post-acute coronary syndrome; quality of life; severity level

\section{Introduction}

Cardiovascular disease is one of illnesses that still causes of high mortality and morbidity rates in the world. Approximately $31 \%$ amount of deaths worldwide are caused by cardiovascular disease (Liu et al., 2019). The prevalence of ACS increases rapidly especially in developing countries, for example in Srilanka which is recognized as having one of the highest causes of death worldwide (Medagama, Bandara, Silva, \& Galgomuwa, 2015). As much as $65 \%$ of deaths occurred when the patients were in pre-hospital phase and did not receive medical care (Beauloye, Vrolix, \& Claeys, 2016).

Indonesia is one of the countries with a high case of heart disease. About 2,650,340 people were diagnosed with a heart disease and the number increases every year (Ministry of Health Republic of Indonesia, 2017). One of the provinces in Indonesia, West Java, contributed 514,597 of them (Ministry of Health Republic of Indonesia, 2014). Acute coronary syndrome is a major cardiovascular problem that causes an increase in the number of hospitalization and mortality rate (Irmalita et al., 2015).

The severity of the disease is described according to coronary artery disease categorization. First, Stable Coronary Artery Disease (Stable CAD) refers to angina pectoris syndrome, including the appearance of recurrent chest pain due to lack of oxygen supply to cells (Liu et al., 2019). While 
Unstable Angina is a condition that is associated with prolonged spontaneous attacks where chest pain can occur even during periods of rest. The last one is Myocardial Infarction (MI). It leads to severe and persistent chest pain, typical ECG changes, and an increase in cardiac biomarkers such as troponin (Thygesen et al., 2018).

The impact of Acute Coronary Syndrome on a patient can affect the quality of life. Patients who have undergone percutaneous coronary intervention experience a decrease in quality of life, related to psychological endurance and selfefficacy. Patients with acute coronary syndrome who have comorbidities like diabetes, hypertension, kidney problems, stress, lack of exercise are described as having a lower quality of life (Bahall \& Khan, 2018). Patients who survive from an acute coronary syndrome attack have lower quality of life in some domains such as general health, physical, mental, and daily activities compared to the general population (Mollon \& Bhattacharjee, 2017).

On the other hand, Kaambwa, Gesesew, and Horsfall (2020) stated that Quality of Life of ACS patients improved after receiving treatments when compared to the baseline status where treatments were not provided. Kaambwa, Gesesew, and Horsfall (2020) also found that patients undergoing $\mathrm{PCl}$ experienced a faster improvement in quality of life compared to CABG procedure. According to the data above, it is necessary to do research about the quality of life of patients after acute coronary syndrome.

Specific instruments are needed to evaluate these conditions. There are some tools to assess the quality of life according to patients' conditions and aspects to be measured. For cardiology and heart disease, the instruments used are such as World Health Organization Quality of Life Assessment Instrument (WHO-QoL), Medical Outcomes Study 6-ite Short-Form Health Survey (SF-36), MacNew Heart Disease Health-Related Quality of Life Questionnaire (MacNew) and so on (Gierlaszyńska, Pudlo, Jaworska, Byrczek-godula, \& Gąsior, 2016).

There are factors that affect the quality of life of patients with acute coronary syndrome, especially myocardial infarction. According to a review of articles conducted, Nurhamsyah, Trisyani, and Nuraeni, (2018) found that there were 5 factors, including biological factors; emotional factors; physical factors; social factors; and psychometric factors. Considering that post-acute coronary syndrome is more general and complicated than myocardial infarction, it is possible that patients suffer more symptoms as well as severity. Moreover, because severity is directly related to many factors above (biological factors, physical factors, and emotional factors) so this study is important to do.

Many studies in emergency ACS patients have been conducted. The approach developed to categorize ACS patients in hospitals is still limited to triage that allows for the best and fast therapy, but an approach to patients after they have gone through an emergency still needs to be done (Crea \& Libby, 2017). Quality of life is one indicator for the success of patient care. An extensible quality of life instrument, particularly for patients with established ACS, is called the Macnew QLMI. However, its use in the service setting has not yet been found.

This is a part of research, which examines the factors associated with the quality of life of patients with post-acute coronary syndrome. Based on reviews, the MacNew Heart Disease HealthRelated Quality of Life Questionnaire can describe the patient's quality of life in detail because it has 3 domains, namely emotional, physical and social. This study uses correlation because researchers want to see specifically the relationship between severity and quality of life of post-acute coronary syndrome patients. Domains on MacNew seem to be correlated with disease severity variables. This study aim was to determine the correlation between severity and quality of life of post-acute coronary syndrome patients at Hasan Sadikin Central Hospital Bandung.

\section{Method}

This research is a quantitative study with a descriptive-analytic design and a cross-sectional approach. This study was conducted on all outpatients with post-acute coronary syndrome who passed the inclusion research criteria and came to the general cardiac clinic and specialists at Hasan Sadikin Central Hospital Bandung in 2019. The inclusion criteria included: patients younger than 70 years who can communicate well; patients who can read and write; and patients with more than 2 weeks post-treatment.

Sampling technique used in this study was consecutive sampling. 100 respondents were taken from June to July 2019. This study has received ethical clearance from two ethical institutions, namely the ethics committee of Hasan Sadikin Central Hospital Bandung with reference LB.02.01/X.6.5/94/2019, and the research ethics committee of Universitas Padjadjaran with reference 532/UN6.KEP/EC/2019. This research process also got approval from the Director of Hasan Sadikin Central Hospital Bandung with letter number LB.02.01/X.2.2.2/8348/2019.

The independent variable in this research was severity level of ACS (based on disorders in the heart blood vessels) which were Angina without Significant Stenosis; coronary 1 stenosis, coronary 2 stenosis; coronary 3 stenosis; coronary 4 stenosis; coronary 5 stenosis, and coronary 6 stenosis (Smith et al., 2006). While the dependent variables were quality of life and its domains. Data on quality of life were collected using the MacNew Quality of Life after Myocardial Infarction Questionnaire (MacNew QLMI) which was approved by the instrument developer (Oldridge, Neil, \& Lim, 1996). This instrument consists of 27 questions describing conditions related to the quality of life of patients with coronary heart disease. The result of the quality 
Table 1. Characteristics of Respondents / Demographic Data $(n=100)$

\begin{tabular}{|c|c|c|c|}
\hline \multirow{3}{*}{ Characteristics } & \multicolumn{2}{|c|}{ Quality of life } & \multirow{3}{*}{ n (\%) } \\
\hline & & & \\
\hline & Good & Poor & \\
\hline \multicolumn{4}{|l|}{ Age (Years) } \\
\hline 17-25 (Teens) & 0 & 1 & 1 \\
\hline 26-45 (Adult) & 5 & 6 & 11 \\
\hline 46-55 (Early elderly) & 18 & 8 & 26 \\
\hline 56-65 (Late elderly) & 20 & 20 & 40 \\
\hline$>65$ & 15 & 7 & 22 \\
\hline \multicolumn{4}{|l|}{ Gender } \\
\hline Male & 48 & 24 & 72 \\
\hline Female & 10 & 18 & 28 \\
\hline \multicolumn{4}{|l|}{ Marital status } \\
\hline Married & 56 & 41 & 97 \\
\hline Single & 2 & 1 & 3 \\
\hline \multicolumn{4}{|l|}{ Last Education } \\
\hline Primary Education (Elementary, Junior High) & 20 & 23 & 43 \\
\hline Secondary Education (High School/equal) & 24 & 13 & 37 \\
\hline Tertiary Education (Diploma, Bachelor, Master) & 14 & 6 & 20 \\
\hline \multicolumn{4}{|l|}{ Employment } \\
\hline Unemployed & 17 & 24 & 41 \\
\hline Private employees / PNS / POLRI / TNI & 21 & 11 & 32 \\
\hline Others (Entrepreneurs, Farmers ) & 20 & 7 & 27 \\
\hline \multicolumn{4}{|l|}{ Income } \\
\hline 1.000.000-2.900.000 (West Java Minimum Wage) & 21 & 24 & 45 \\
\hline $3.000 .000-3.500 .000$ & 14 & 7 & 21 \\
\hline$>3.500 .000$ & 23 & 11 & 34 \\
\hline \multicolumn{4}{|l|}{ Comorbidities (Related to Cardiac) } \\
\hline Diabetes / Hypertension / Kidney Disease & 13 & 13 & 26 \\
\hline More than 1 disease & 7 & 10 & 17 \\
\hline Without comorbidity (Diabetes / Hypertension / Kidney Disease ) & 38 & 19 & 57 \\
\hline
\end{tabular}

of life data can be divided into two categories based on cut off points, which are good and poor (Oldridge, Neil, \& Lim, 1996). The validity test conducted by the researcher showed the value of $r$ count $>r$ table (0.196) on all question items ( $r$ count P1-P27: 0.4860.799 ). The instrument is also declared reliable with Chronbach's alpha value of 0.937 . It means that every single question in this questionnaire is valid and reliable.

Researchers conducted univariate and bivariate analyses in this study. The univariate analysis conducted by researchers includes the characteristics of each variable. The bivariate analysis used was Somers'd Gamma to assure the relation between independent and dependent variabels. The Somers'd Gamma test was chosen because the scale of data on severity and quality of life is an ordinal scale.

\section{Results}

Based on table 1, the respondent characteristics can be seen. 40 respondents (40\%) were 56-65 years old or in the final elderly stage. The most of respondents' gender (72\%) were male and the marital status was married (97\%). The most recent level of education taken by respondents was mostly at the basic education level, which were accounted for 43 respondents (43\%). The majority of the respondents' indigenous tribes were Sundanese with 86 people ( $86 \%)$. The respondents' employment status was mostly unemployed $(41 \%)$ and as many as 45 respondents $(45 \%)$ had monthly income under the minimum wage of West Java province (Rp. 1,000,000-Rp. 2,900,000). On average, there were 57 respondents $(57 \%)$ who did not have other comorbidities.

Based on table 2, it can be seen that more 
Table 2. Characteristics of Variables $(n=100)$

\begin{tabular}{|c|c|c|c|}
\hline \multirow{2}{*}{ Characteristics } & \multicolumn{2}{|c|}{ Quality of Life } & \multirow{2}{*}{ n (\%) } \\
\hline & Good & Poor & \\
\hline Good & & & 58 \\
\hline Poor & & & 42 \\
\hline \multicolumn{4}{|l|}{ Emotional Domain } \\
\hline Good & 55 & 9 & 64 \\
\hline Poor & 3 & 33 & 36 \\
\hline \multicolumn{4}{|l|}{ Physical Domain } \\
\hline Good & 50 & 2 & 52 \\
\hline Poor & 8 & 40 & 48 \\
\hline \multicolumn{4}{|l|}{ Social Domain } \\
\hline Good & 52 & 8 & 60 \\
\hline Poor & 6 & 34 & 40 \\
\hline \multicolumn{4}{|l|}{ Severity Level } \\
\hline Angina without Significant Stenosis & 15 & 21 & 36 \\
\hline Coronary 1 Stenosis & 21 & 8 & 29 \\
\hline Coronary 2 Stenosis & 2 & 4 & 6 \\
\hline Coronary 3 Stenosis & 7 & 5 & 12 \\
\hline Coronary 4 Stenosis & 8 & 1 & 9 \\
\hline Coronary 5 Stenosis & 4 & 3 & 7 \\
\hline Coronary 6 Stenosis & 1 & 0 & 1 \\
\hline
\end{tabular}

Table 3. Bivariate Analysis Between Independent Variables and Dependent Variables in Post Acute Coronary Syndrome Patients at Hasan Sadikin Central Hospital Bandung in 2019

\begin{tabular}{ccccc}
\hline \multirow{2}{*}{ Variable } & \multicolumn{4}{c}{ Coefficient of Correlation/Approx. Sig. } \\
\cline { 2 - 5 } & QOL & Emotional & Physical & Social \\
\hline Level of Severity & ${ }^{*} 0.033$ & 0.070 & ${ }^{*} 0.008$ & 0.149 \\
\hline${ }^{*} p<0.05$ & & &
\end{tabular}

than half of the respondent (58 respondents) after acute coronary syndrome had good quality of life. Conditions with a good result can also be found in each quality of life domain, namely the emotional domain with 64 respondents $(64 \%)$, the physical domain with 52 respondents $(52 \%)$, and the social domain with 60 respondents $(60 \%)$. The table also showed cross tabulation between severity level and the quality of life. The severity level was based on disorders in the heart blood vessels, the most experienced angina pectoris/chest pain with 36 respondents $(36 \%)$, followed by respondents who experienced blockages in 1 heart blood vessel with 29 respondents $(29 \%)$.

Based on table 3 , there is a significant relation between severity and quality of life of patients after acute coronary syndrome $(p=0.033)$. In addition, there is also a significant relation between severity and physical domain quality of life of patients after acute coronary syndrome $(p=0.008)$.

\section{Discussion}

This research found that more than half of the patients after acute coronary syndrome at Hasan Sadikin Central Hospital Bandung had good quality of life. It is also shown that more than fifty percent of patients had good scores in each domain of quality of life. A systematic review by Kaambwa et al. (2020) found that quality of life of acute coronary syndrome patients increased after recieving treatments therapies, which was in line with this research where the data were collected two weeks after treatment.

The severity level and quality of life of patients after acute coronary syndrome had a significant correlation. This is appropriate with the study by Moriel, Roscani, Matsubara, Teresa, and Cerqueira (2010) which revealed that severity level affects the quality of life of patients after acute coronary syndrome. The severity level had a negative correlation with quality of life, higher severity level 
caused lower quality of life. This is in line with Padilla, Martın-Asenjo, and Bueno (2017) who stated that the increase of severity level of acute coronary syndrome increased the risk of disability and lowered the quality of life.

The physical domain was a domain that had correlation with the severity level. It is in line with the research (Zaben \& Khalil, 2019) which stated that physical domain is the most affected in post-acute coronary syndrome patients. It can be caused by the physical domain of quality of life score, where there were $48 \%$ of respondents who had a poor quality of life and the severity of the disease was closely related to the physical domain of the patient. This finding is in line with a research by Nuraeni et al. (2016), that the focus on improving the quality of life of patients with coronary heart disease is still on the physical aspects. Physical limitations due to coronary heart disease cause a change in one's role (Rosidawati, Ibrahim, \& Nuraeni, 2016).

Findings of this study where 43 respondents had comorbidities such as hypertension, diabetes, kidney disease or both could be a possible cause that made more than $30 \%$ respondent had poor quality of life. Kim et al. (2013) found at their study that comorbidities such as hypertension and diabetes in patients with unstable angina and older age NSTEMI increase the severity and decrease the quality of life. In line with those findings, Moriel et al. (2010) also said the same thing that patients' quality of life were exacerbated by obesity, comorbidities such as diabetes mellitus and uncontrolled hypertension.

Another study by Kim et al., (2013) stated that the condition of patients with unstable angina and long-term NSTEMI had a worse outcome than STEMI patients. They stated that although PCI was an effective treatment for treating patients with acute myocardial ischemia, it turned out that its benefits for the improvement of general health conditions would not be sufficient, but they need for more specific angina therapy support such as comprehensive supportive care. This is appropriate with this study findings which found that $21 \%$ of respondents who experienced angina pectoris had a poor quality of life. This further strengthens that the quality of life of the respondents is $58 \%$ in the good category. It may be affected or caused by finding that there were still $21 \%$ of respondents who experienced angina pectoris had not received revascularization interventions yet.

\section{Conclusion}

Based on the results of research that has been done, it can be concluded that more than half of patients after acute coronary syndrome in Hasan Sadikin Central Hospital Bandung had good quality of life. Likewise, in each domain of quality of life, such as emotional, physical, and social domains, the quality of life of more than half of the respondents was good.

There was a correlation between severity level and quality of life of patients post-acute coronary syndrome in Hasan Sadikin Central Hospital Bandung. The severity level had a negative correlation with quality of life, higher severity level caused lower quality of life. Based on the quality of life domain, the severity level was significantly related to the physical-domain. Considering that, regular screening is necessary to improve the quality of life of patients after acute coronary syndrome. Future studies are needed to reveal data related to the length of diagnosis of acute coronary syndrome with quality of life.

\section{References}

Bahall, M., \& Khan, K. (2018). Quality of life of patients with first-time AMI: a descriptive study. Health and quality of life outcomes, 16(1), 32. https://doi.org/10.1186/s12955-018-0860-8

Beauloye, C., Vrolix, M., Claeys, M. J., van de Borne, P., Vandendriessche, E., \& Van De Werf, F. (2016). Pre-hospital management of acute coronary syndrome patients in Belgium and Luxembourg and other Western European countries. Acta cardiologica, 71(1), 15-24. https://doi.org/10.2143/AC.71.1.3132093

Crea, F., \& Libby, P. (2017). Acute Coronary Syndromes. American Heart Journal, 136(12), 1155-1166. https://doi.org/10.1161/ Circulationaha.117.029870

Gierlaszyńska, K., Pudlo, R., Jaworska, I., ByrczekGodula, K., \& Gąsior, M. (2016). Tools for assessing quality of life in cardiology and cardiac surgery. Kardiochirurgia $i$ torakochirurgia polska: Polish journal of cardio-thoracic surgery, 13(1), 78-82. https:// doi.org/10.5114/kitp.2016.58974

Irmalita, I., Juzar, D. A., Andrianto, A., Setianto, B. Y., Tobing, D. P., Firman, D., \& Firdaus, I. (2015). Pedoman tatalaksana sindrom koroner akut. Jurnal Kardiologi Indonesia (Guidelines for the management of acute coronary syndromes. Indonesian Heart Association

Kaambwa, B., Gesesew, H. A., \& Horsfall, M. (2020). Quality of life changes in acute coronary syndromes patients: A systematic review and meta-analysis. International Journal of Environtmental Research and Public Health, 17(18). https://doi.org/10.3390/ijerph17186889

Kim, M. J., Jeon, D. S., Gwon, H. C., Kim, S. J., Chang, K., Kim, H. S., Tahk, S. J., \& KOREAN MUSTANG Investigators (2013). Healthrelated quality-of-life after percutaneous coronary intervention in patients with UA/ NSTEMI and STEMI: the Korean multicenter registry. Journal of Korean medical science, 28(6), 848-854. https://doi.org/10.3346/ jkms.2013.28.6.848

Liu, N., Liu, S., Yu, N., Peng, Y., Wen, Y., Tang, J., \& Kong, L. (2018). Correlations among psychological resilience, self-efficacy, and negative emotion in acute myocardial 
infarction patients after percutaneous coronary intervention. Frontiers in psychiatry, 9(1). https://doi.org/10.3389/fpsyt.2018.00001

Liu, H., Chen, X., Hu, X. et al. (2019). Alterations in the gut microbiome and metabolism with coronary artery disease severity. Microbiome 7(68). https://doi.org/10.1186/s40168-0190683-9

Medagama, A., Bandara, R., Silva, C. De, \& Galgomuwa, M. P. (2015). Management of acute coronary syndromes in a developing country; time for a paradigm shift? An observational study. BMC Cardiovascular Disorders, 15(133), 1-8. https://doi. org/10.1186/s12872-015-0125-y

Ministry of Health Republic of Indonesia. (2014). Info Datin Pusat Data Dan Informasi Kementrian Kesehatan RI. (Infodatin Center for Data and Information of the Indonesian Ministry of Health.) Kemenkes RI, 109(1), 1-8. https://doi. org/10.1017/CBO9781107415324.004

Ministry of Health Republic of Indonesia. (2017). Penyakit jantung penyebab kematian tertinggi, Kemenkes ingatkan CERDIK, (Heart disease is the highest cause of death, Ministry of Health reminds CERDIK). Retrieved December 03, 2020, from www.depkes.go.id

Mollon, L., \& Bhattacharjee, S. (2017). Health related quality of life among myocardial infarction survivors in the United States: a propensity score matched analysis. Health and quality of life outcomes, 15(1), 235. https://doi. org/10.1186/s12955-017-0809-3

Moriel, G., Roscani, M. G., Matsubara, L. S., Cerqueira, A. T., \& Matsubara, B. B. (2010). Quality of life in patients with severe and stable coronary atherosclerotic disease. Arquivos brasileiros de cardiologia, 95(6), 691-697. https://doi.org/10.1590/s0066782x2010005000151
Nuraeni, A., Mirwanti, R., Anna, A., \& Prawesti, A. (2016). Faktor yang memengaruhi kualitas hidup pasien dengan penyakit jantung koroner. (Factors affecting quality of life of patients with coronary heart disease.) Jurnal Keperawatan Padjadjaran, 4(2). https://doi.org/10.24198/jkp. v4i2.231

Nurhamsyah, D., Trisyani, Y., \& Nuraeni, A. (2018). Quality of life of patients after acute myocardial infarction : A scoping review. Journal of Nursing Care, 1(3), 180-191. https://doi.org/10.24198/ jnc.v1i3.18517

Oldridge, Neil., Lim, L. (1996). MacNew Quality of Life After Myocardial Infarction Questionnaire. MacNew QLMI.

Padilla, I. M., Martın-Asenjo, R., \& Bueno, H. (2017). Management of acute coronary syndromes in geriatric patients. Heart, Lung and Circulation, 26(2), 107-113. https://doi.org/10.1016/j. hlc.2016.07.008

Rosidawati, I., Ibrahim, K., \& Nuraeni, A. (2016). Kualitas hidup pasien pasca bedah pintas arteri koroner (BPAK). (Quality of Life of Patients Post Coronary Artery Bypass Surgery (BPAK)). Jurnal Keperawatan Padjadjaran, 4(2). https://doi.org/10.24198/jkp.v4i2.238

Smith, S. C., Feldman, T. E., Hirshfeld, J. W., Jacobs, A. K., Kern, M. J., lii, S. B. K., ... Practice, S. (2006). Guideline Update for Percutaneous Coronary Intervention. American Heart Journal. https://doi.org/10.1161/ CIRCULATIONAHA.106.173220

Thygesen, K., Alpert, J. S., Jaffe, A. S., Chaitman, B. R., Bax, J. J., Morrow, D. A., \& White, H. D. (2018). Fourth Universal Definition of Myocardial Infarction. https://doi.org/10.1161/ CIR.0000000000000617

Zaben, K., \& Khalil, A. (2019). Health Literacy, SelfCare Behavior and Quality of Life in Acute Coronary Syndrome Patients: An Integrative Review. Scientific Research Publishing, 9, 383395. https://doi.org/10.4236/ojn.2019.94035 